\title{
Capturing and Understanding the Dynamics and Heterogeneity of Gene Expression in the Living Cell
}

\author{
Amparo Pascual-Ahuir ${ }^{1, *}$, Josep Fita-Torró ${ }^{2}$ and Markus Proft ${ }^{2, *}$ (D) \\ 1 Department of Biotechnology, Instituto de Biología Molecular y Celular de Plantas, Universitat Politècnica \\ de València, 46022 Valencia, Spain \\ 2 Department of Molecular and Cellular Pathology and Therapy, Instituto de Biomedicina de Valencia \\ IBV-CSIC, 46010 Valencia, Spain; jfita@ibv.csic.es \\ * Correspondence: apascual@ibmcp.upv.es (A.P.-A.); mproft@ibv.csic.es (M.P.); \\ Tel.: +34-96-3877770 (A.P.-A.); +34-96-3391769 (M.P.)
}

Received: 23 September 2020; Accepted: 3 November 2020; Published: 5 November 2020

\begin{abstract}
The regulation of gene expression is a fundamental process enabling cells to respond to internal and external stimuli or to execute developmental programs. Changes in gene expression are highly dynamic and depend on many intrinsic and extrinsic factors. In this review, we highlight the dynamic nature of transient gene expression changes to better understand cell physiology and development in general. We will start by comparing recent in vivo procedures to capture gene expression in real time. Intrinsic factors modulating gene expression dynamics will then be discussed, focusing on chromatin modifications. Furthermore, we will dissect how cell physiology or age impacts on dynamic gene regulation and especially discuss molecular insights into acquired transcriptional memory. Finally, this review will give an update on the mechanisms of heterogeneous gene expression among genetically identical individual cells. We will mainly focus on state-of-the-art developments in the yeast model but also cover higher eukaryotic systems.
\end{abstract}

Keywords: gene expression; transcriptional activation; transcriptional memory; single-cell variability; reporter assays; stress adaptation; transcriptional dynamics

\section{Introduction}

The modulation of gene expression is a key feature of all living organisms and permits the adjustment of the protein composition of a cell in response to infinite environmental cues or during differentiation processes [1-3]. Traditionally, the expression rate of a gene has been measured by the quantification of its product, either mRNA or protein, using invasive methods, which generally impede the detection of the true dynamic nature of gene expression regulation. In the past decades, numerous approaches have been developed to study gene expression in real time and in the living cell by the introduction of different fluorescent or bioluminescent reporters or in situ hybridization techniques. This has greatly advanced our perception of the highly dynamic nature of transcriptional regulation $[4,5]$. It is clear now that the dynamics of transient gene expression is crucial for the appropriate cellular adaptation to changing environments [6], as is the timing and pattern of gene regulation fundamental for the fate of developmental programs [7]. In eukaryotic organisms, the activation of gene expression is a multistep process including transcription factor (TF) association with upstream control regions or enhancers, chromatin modification and remodeling, recruitment of co-activators and RNA polymerase, transcriptional elongation and termination, mRNA modification, and nuclear export. At each of these steps, gene expression dynamics can be modulated for specific genes. Please refer to excellent reviews for the mechanistic details of eukaryotic gene expression regulation in general [8-11], which is not the aim of this overview. In this review, we will focus on the molecular steps, from signal transduction 
to active gene transcription, which confer dynamic gene- and cell-specific regulation (Figure 1). We will summarize the mechanisms that modulate the expression rates of genes according to different physiological determinants of the organism and compare methods for the in vivo determination of dynamic gene expression.

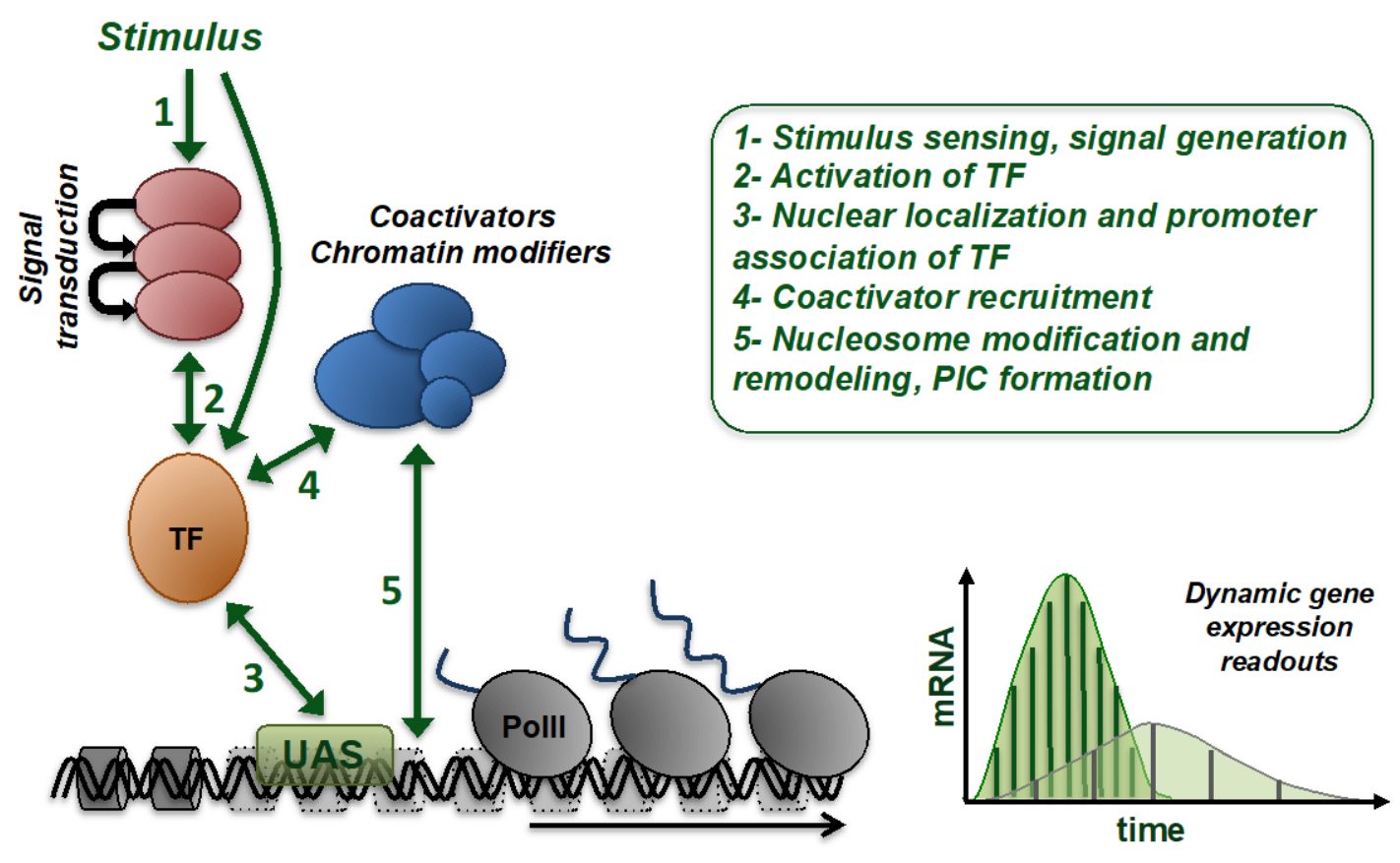

Figure 1. Determinants of dynamic transcriptional regulation of eukaryotic genes. Schematically are shown the processes that can modulate the timing and efficiency of activated gene expression. A given stimulus can give rise to different gene expression patterns in a gene- and cell-specific manner. TF, transcription factor, UAS, upstream activating sequence, PolII, RNA polymerase II, PIC, preinitiation complex.

\section{Technical Approaches to Capture Gene Expression In Vivo}

Traditional methods measure gene expression by the invasive determination of its final mRNA product by RT-PCR or Northern blotting or of the activity of a reporter protein such as $\beta$-galactosidase. Although, in principle, these techniques can infer the dynamics of gene expression in cell populations by serial sample preparation, the resolution and applicability to different parallel conditions of these approaches are limited. More directly, RNA polymerase II (PolII) association with target genes during activation can be dynamically estimated by kinetic chromatin immunoprecipitation (ChIP) techniques [12-14]. However, the comparison of transcriptional kinetics is very laborious with the ChIP approach.

Another way to quantify the dynamics of transcription is the direct visualization of the nascent mRNA by in vivo imaging procedures [15]. This was first established, together with other microscopic techniques, by Janicki et al. [16] in order to get a closer look at the true kinetics of the gene expression process in a living cell. One strategy to visualize mRNA molecules in vivo is the introduction of multiple sequence tags into the gene of interest, which form characteristic stem-loop structures in the corresponding mRNA molecule, recognized by detector proteins fused to fluorescent markers. Common detection systems rely for example on the specific recognition of tertiary RNA structures by the MS2 or PP7 bacteriophage coat proteins $[17,18]$. Instantaneous detection of nascent mRNA molecules by this method has enabled studies of transcription dynamics in living cells from bacteria to humans [19-23]. Very recent approaches combine in vivo labeling of DNA, nascent RNA, and a fluorescent protein to resolve the spatiotemporal process of transcriptional induction at a single locus [24]. Although these approaches are highly sensitive and are applicable at single-cell resolution, they require engineered 
genes for visualization and are generally time-consuming, which greatly limits the parallel study of several genes or their application to diverse conditions that modulate transcriptional dynamics.

A versatile way to quantify gene expression changes in vivo is the use of short-lived fluorescent proteins or luciferases in reporter gene assays. Although these approaches are not specific for transcription, they allow the continuous monitoring of gene expression in real time with little experimental effort. Typically, the fluorescent or bioluminescent protein is expressed from the control region of interest, either on plasmids or integrated in the genome, and protein synthesis is quantified over time by time-lapse microscopy, fluorescence cytometry, or fluorescence or luminescence readers. Fluorescent markers such as green fluorescent protein (GFP) are the most widely used indicators for dynamic in vivo gene expression studies [25-27] because of their high photon yield that is compatible with time-elapsed studies in single cells [28-30]. Additionally, GFP activity does not depend on additional cellular cofactors, and engineered versions with different colors are available for the simultaneous visualization of gene expression from several loci in the same cell [31]. However, several limitations exist that make fluorescent proteins a less suitable approach, especially for the faithful detection of transient and highly dynamic fluctuations of gene expression. Fluorescent proteins of the GFP family are very stable, which is a serial constraint for a good resolution of transient gene expression. Therefore, destabilized GFP variants have been developed [32-34], which, however, still show considerable half-lives of at least $30 \mathrm{~min}$ and loss of signal output [35]. Furthermore, GFP shows a slow maturation that is an additional obstacle for the real-time visualization of fast transcriptional responses. Furthermore, the continuous monitoring of fluorescent protein activity requires external excitation with high-energy light sources, which causes problems of autofluorescence and phototoxicity.

Many of these inconveniences of fluorescent markers for gene expression studies can be avoided by the use of bioluminescent proteins such as luciferases as reporters. Luciferases do not require external excitation and are co-translationally active. Additionally, unstable versions of firefly and other luciferases have been created for time-elapsed gene expression studies, from bacteria to human cells [36-38]. The destabilization of the firefly luciferase by the addition of combined protein and mRNA degradation motifs has been especially useful in the yeast model, where these tools allow real-time monitoring of gene expression fluctuations with unprecedented resolution [39-42]. Although luciferase reporters have significantly lower signal levels and are normally used in cell populations, continuous single-cell gene expression studies are technically possible with unstable luciferase reporters in yeast cells [42]. Bioluminescent reporters, however, pose yet other technical challenges for the continuous measurement of gene activity over time. The specific substrate for the luciferase enzyme, e.g., luciferin in the case of the firefly enzyme, has to be provided externally at sufficient concentration for long-term studies. Also, luciferase activity depends on oxygen and ATP levels, which might additionally have an influence on the light emission levels obtained during prolonged live cell assays.

The techniques described above enable researchers to quantitate dynamic gene expression events by measuring the final product of the process. In the past years, also the visualization of individual TFs and their dynamic interaction with genomes and cis-regulatory elements at the single-cell and single-molecule levels has greatly enhanced our models of eukaryotic gene activation $[43,44]$.

\section{Activated Gene Expression: A Highly Dynamic Dose-Dependent Biological Function Sensitive to Many Physiological and Genetic Factors}

Gene expression changes upon external stimuli often affect many genes simultaneously in order to adapt the organism to the changing environment. Transient transcriptional activation is largely dependent on the strength of the stimulus or stress. Recent applications of time-elapsed luciferase reporters have revealed the dose-dependent dynamics of these responses by simultaneously measuring gene expression upon continuously increasing stimulation $[39,45]$. The resulting dose-response (DR) profiles contain information about how cells adjust gene expression upon dynamic environmental 
signals (Figure 2) [46]. A typical DR profile shows very little transcriptional activation upon low threshold stimulation, which is continuously increased until reaching a maximal transcriptional output upon the optimal stimulation in the dynamic range. Further increases in stimulation do not further enhance gene expression but in many occasions lead to delayed and/or less efficient expression due to inhibition of the gene expression process by harsher induction conditions. It is important to note that an apparently low transcriptional response in cell populations can be produced when only a fraction of the cells actually respond to the stimulation. This phenomenon called bimodal gene expression has been found in several transcriptional responses to environmental changes and occurs often at threshold stress levels [47-49].

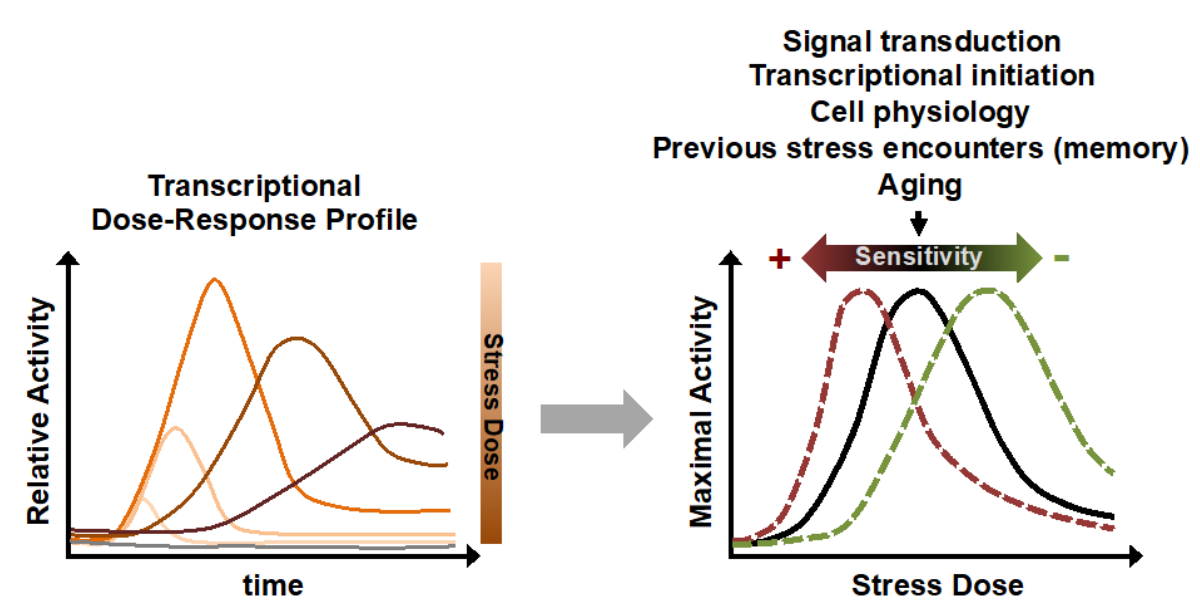

Figure 2. Transcriptional dose-response profiles and their modulation. Continuous monitoring of gene expression quantifies the response of a cell population for a specific gene at any possible stress dose (dose-response (DR) profile, depicted on the left). The responsiveness of gene expression over a stress gradient can dynamically change, as shown on the right. For different genes, the sensitivity of the dose-response might depend on differential signal transduction or on the ability of each gene to engage in active transcription. The same gene might show different DR profiles in cells with altered physiology, different age, or after repeated stress responses.

There are many factors which modulate the DR profile of the same or of different genes and cause shifts towards more or less sensitive behaviors (Figure 2). One is the intrinsic promoter structure. Quantitative studies in yeast populations have shown that different promoters have distinguishable sensitivities towards the same abiotic stresses such as osmotic or oxidative challenges, resulting in different half-maximal stimulus concentrations [45]. It has been recently elucidated that the dynamic of a transcriptional stress response is modulated at both levels of transcription rate and duration and that the gene expression output is modulated at different stages by multiple genetic determinants [50]. Detailed studies of specific inducible yeast promoters have been undertaken successfully to improve the accessibility and affinity of TF binding sites in artificial promoters to create gene expression responses with altered dynamics [51-53].

The ability to study transcriptional regulation at the single-locus level has advanced our model of how genes switch from an inactive to an active state in a stochastic manner [54]. This phenomenon is called transcriptional bursting and describes how an inactive locus can switch to the active synthesis of active nascent RNA for a limited period, allowing transcription of several RNA polymerases simultaneously. Both the timing and the frequency of the burst can be subject to regulation, thereby adjusting gene expression to specific stimuli. The transcriptional burst itself is not a subject of this review, and the interested reader is referred to excellent recent review articles $[55,56]$. Here, we are interested in the molecular mechanisms which favor or disfavor bursting at specific genes. The critical limiting steps prior to the formation of the preinitiation complex (PIC) and transcriptional initiation are transcriptional activator binding and chromatin and nucleosome remodeling. Large-scale mutagenesis 
approaches using yeast promoters confirmed that indeed the upstream regulatory sequence is generally responsible for high transcriptional activation [57]. Complementary to these studies, the introduction of nucleosome disfavoring sequences in promoters largely favored active gene expression [58], and modulating the extension of nucleosome-free regions is an important manner to dynamically tune the transcriptional activity of a genetic locus [59]. This indicates that facilitating a stable activator contact with its cognate promoter DNA is one of the rate-limiting steps in dynamic transcriptional activation. Systematic studies in yeast have confirmed this and shown that in most cases, the amount of activator protein, rather than the amount of binding sites, is the major determinant of gene expression rate [60]. Studies of individual yeast TFs at the single-molecule level revealed that unspecific target binding is common for different TFs, while coordinated chromatin remodeling is necessary for dynamic TF association and transcriptional bursting [61,62]. In general, the timing of transcriptional initiation and the efficiency of mRNA production seem to be linked to different recycling dynamics of TFs [63]. Very recently, the application of simultaneous visualization techniques for TF binding and RNA production at a single locus has permitted to directly correlate Gal4 activator binding with the amount of RNA produced from different Gal4-regulated genes in a process which is highly dependent on the presence of nucleosomes [64]. Single-molecule experiments at the GAL1/GAL10 locus furthermore indicated that transcription of non-coding (nc)RNAs can dynamically regulate gene expression and adjust different activation thresholds [65]. Also, for metazoan genes, the efficient recruitment of transcriptional activators and coactivators proximal to the transcriptional start site seems to be essential for dynamic gene activation. This has been reported for the proto-onco gene $c F o s$ and for a glucocorticoid-regulated reporter gene $[66,67]$. Specific mammalian TF levels are critical for creating dynamic transcriptional behaviors for various genes [68,69]. Additionally, nuclear architecture is an important determinant for target finding for individual TFs, according to single-molecule tracking experiments [70]. Generally, also in higher eukaryotic systems, the number and affinity of cis-regulatory elements in promoters is decisive for the dynamics of transcriptional bursting [71,72]. Stem cell bursting dynamics have been recently found to be regulated by a combination of chromatin-remodeling complexes and signal transduction pathways [73]. For developmental gene regulation in Drosophila, it has been recently shown that dynamic morphogen gradients modulate different bursting parameters to ensure graded mRNA synthesis at single loci during embryo development [74,75].

Chromatin remodeling is often the rate-limiting process affecting the transcription rates of eukaryotic genes [76]. Since the cell can keep different chromatin states or marks at specific genomic regions, these elements are important both for the short-term activation of environmental stress-responsive genes (discussed here) and for long-term memory effects (discussed in the next chapter). The requirement for nucleosome remodeling to ensure activator binding and/or stable PIC formation might be very variable at different inducible loci or for different physiological states of the cell. Thus, the efficient switch from an inactive to an active chromatin state modulates transcriptional dynamics in an important manner [76,77]. In yeast, several inducible genes such as PHO5, INO1, GAL1, SUC2, GRE2, CUP1, HO and others have been studied in detail to understand how the timely recruitment of co-activator complexes, which modify and remodel nucleosomes at the promoter chromatin, promotes dynamic transitions to the on state of genes responsive to diverse environmental stimuli [78-83]. In many cases, a functional interplay between different complexes such as SWI/SNF2, ISWI, CHD, INO80 ATPase-containing remodelers and SAGA, Rpd3 histone modifiers, or the mediator complex has been documented [78,79,84-89]. It is important to note that the time needed for efficient PIC formation after the first stimulation spans a wide range, from one or few minutes (typically, at acute stress-responsive genes) to hours (at nutrient-responsive or developmental genes). For example, a first induction of the nutrient-responsive GAL1 gene is slow and requires intensive chromatin modifications for active Gal4 binding, PIC assembly at the promoter, and dynamic initiation [90-92]. This also leads to a pronounced bimodal expression at medium or low galactose concentrations, which is dependent on chromatin remodeling activities $[90,93]$. As a result, GAL1 and similar slow-responding genes are prone to faster activation upon repeated stimulation by epigenetic and other mechanisms, 
as discussed in the next chapter. On the other hand, fast-responding stress genes such as the GRE2, other osmostress-responsive genes, or genes responding to xenobiotic insults are characterized by the rapid engagement of a pre-bound TF in PIC formation upon co-activator recruitment $[88,94,95]$. Accordingly, those genes do not show or have very little positive memory upon repeated exposure to the stressor $[90,94]$.

Looking more upstream from transcriptional initiation, it is important to understand the dynamic signaling events which further increase the sensitivity of gene expression. External and internal signals are usually transmitted to specific TFs either directly or indirectly via signal transduction pathways. Frequently, activation derives from the direct binding of the TF to chemical compounds such as hormones, metal ions, or xenobiotics or from a post-translational modification of the TF, such as phosphorylation. As a result, the activated TF can acquire one or more of the following functionalities: enhanced nuclear retention and/or enhanced association with the cognate DNA motif, weakening of inhibitory factors, and favored recruitment of chromatin-modifying coactivators and PolII complexes. It is important to note that the dynamics of gene induction upon a given stimulus depends on how efficiently the TF is responsive to the stimulation. The same stress might provoke different gene expression outputs depending on the specific TF involved. For example, various transcriptional activators participate in the yeast osmostress response, and all receive a phosphorylation signal from the upstream stress-activated protein kinase (SAPK) Hog1, upon osmotic stress. Here, the TF Sko1 has been found to more sensitively activate gene expression as compared to several other TFs [46], which might enable the cell to adapt to a stress with a hierarchical response, employing differentially sensitive transcriptional activators. Other examples are xenobiotic binding TFs of the Pdr family in yeast, which very recently have been shown to transmit different gene activation dynamics by the distinguishable recognition of chemically divergent compounds [94]. On the other hand, an opposing, signal-integrating function has been described for the general stress-responsive transcriptional activator Msn2, which is able to process up to four different stress inputs into distinguishable dynamic transcriptional outputs based on its regulation of nuclear import and export [96-98].

To fully understand how cells respond to environmental cues by modulating gene expression, it is important to consider cells' physiology. One has to keep in mind that cells in many cases engage in activated gene expression in order to overcome a particular disruption of their homeostasis and eventually return to the equilibrium state. The amount of gene regulation needed for this compensation is often dependent on the physiological properties of the cell. A simple example illustrates this dependence. It has been shown that yeast cells adapted to rich growth conditions tend to transcriptionally respond to abiotic stresses at lower doses, which could be explained by a more repressed general stress defense as compared to cells adapted to minimal growth conditions [46]. In the same vein, osmotic stress causes transcriptional adaptation at significantly lower stress concentrations in galactose- as opposed to glucose-grown cells, because galactose metabolism does not allow an efficient osmoprotection in budding yeast $[99,100]$. These examples illustrate that the physiological properties of a cell are important modulators of the sensitivity and dynamics of its transcriptional response to many stressors.

Cellular aging is a specific physiological change that has consequences for the dynamics of gene expression [101]. Work in the yeast model has shown that cell-to-cell heterogeneity of gene expression, also called transcriptional noise, increases in aged cells due to the lower expression of histone genes [102]. This global deregulation of precise gene expression control is manifested by the overall loss of promoter nucleosomes with advanced age [103]. Further studies revealed that the maintenance of a specific histone mark-H3K36 methylation-was critical to avoid transcriptional leakage during aging [104]. These data suggested that global changes in chromatin structure occur in old yeast populations, leading to an increase in transcriptional noise and a decrease in transcriptional fidelity [105]. However, by monitoring specific reporter genes in single yeast cells, noise reduction during normal aging has been reported, with a complete deregulation at the final stages of the aging process [106]. Also in individual mammalian cells, a great increase of transcriptional diversity has 
been found during aging [107-111]. Additionally, chromatin rearrangements of different magnitude have been reported in old mammalian cells and lead to altered gene expression dynamics for several genes [112-116]. Another important change in gene expression dynamics occurs in old cells at the level of rapid gene activation upon stress signals. Aging yeast populations show an increasing loss of efficiency, dynamics, and timing of oxidative stress-responsive reporter genes [46]. In T cells from old mice, the immune response is less tightly regulated, and an inefficient and heterogeneously uncontrolled transcriptional response has been found [117]. These data indicate that the loss of a timely and efficient transcriptional activation upon cellular stress might contribute to aging-related cellular and organismal dysfunctions [101,118,119].

Another important factor which shapes the transcriptional response to a given stimulus is cells history. Very often, a previous encounter with the same or related stress determines the transcriptional response in a later, repeated encounter. An improved response by means of transcriptional memory, as detailed in the next chapter, is only one of several scenarios. Indeed, transcriptional memory can be separated from acquired tolerance mechanisms in yeast, and both contribute to an enhanced fitness after a previous stress insult [120]. Furthermore, the prevalent behavior depends on the combination of different stress experiences. For example, repeated oxidative stress in yeast leads to a more efficient transcriptional activation [46,120], while repeated salt stress makes cells less responsive [90,121]. A combination of both stresses induces a mixed behavior, with cells responding less at low doses and more efficiently at high stress doses [46]. Additionally, it has been reported that a first round of xenobiotic-induced gene expression is very efficient in yeast cells, while a shortly repeated stimulation leads to a significantly reduced transcriptional activation [94]. This behavior can be explained by the rapid degradation of the main xenobiotic-regulated TF, Pdr1, after its activation [94].

\section{Epigenetic Transcriptional Memory: Modulating Gene Expression Dynamics upon Repeated Stimulation}

An important mechanism that changes the expression dynamics of genes is epigenetic transcriptional memory. This phenomenon has been found in many organisms and describes the fact that a response to a previous environmental stimulus alters the dynamics of gene expression upon subsequent stimulation [122,123]. These heritable changes normally last during several cell generations and might permit the organism to respond faster and more efficiently to periodically occurring environmental challenges. For example, human cells memorize past infections by favoring interferon- $\gamma$-mediated gene induction [124], and plants show an enhanced transcriptional response to heat shock several days after a previous heat stress [125-127]. Budding yeast has been used very extensively in transcriptional memory investigation, because several nutritional changes induce profound memory effects, which can be easily studied in depth in this organism. Two genetic systems and environmental conditions have been mainly applied in yeast: the induction of the GAL genes (encoding the enzymes necessary for galactose utilization), which show strong epigenetic memory upon repeated exposure to galactose, and the expression of the INO1 gene (encoding inositol-1-phosphate synthase), which is activated by inositol starvation and potentiated upon previous inositol deprivation (Figure 3).

In naïve yeast cells, induction of the $G A L$ genes is slow and requires high inducer concentrations to be efficient. After a previous galactose encounter, this response is significantly faster and more sensitive to low galactose concentrations, and this memory state is maintained as long as through seven generations $[90,91,128]$. Different molecular mechanisms have been identified so far to explain the establishment of GAL memory. One mechanism is chromatin-based and leads to the relocalization of the $G A L$ gene to the nuclear periphery, where it physically associates with the nuclear pore complex (NPC) upon the first induction $[128,129]$. The NPC subunit Nup100, the H2A.Z histone variant, and specific GAL1 promoter sequences are important for this translocation [129]. GAL1 tethering to the nuclear periphery is maintained even in the absence of active $G A L$ gene transcription. However, disruption of GAL1 interaction with the NPC did not affect GAL1 transcriptional memory, which implies other 
memory mechanisms in the case of GAL genes [129]. Accordingly, it has been suggested that enhanced GAL induction during memory largely depends on the accumulation of signaling molecules, such as the Gal1 and Gal3 proteins [90,130,131] (Figure 3). Both factors bind to the Gal80 repressor [132], which inhibits GAL gene expression by masking the activator domain of the Gal4 transcriptional activator. Therefore, previous induction of Gal1/Gal3 can promote a faster activation by more efficiently counteracting GAL repression through reinforced signaling during memory. Indeed, the degree of GAL memory seems to correlate with the expression levels of Gal1 or Gal3 [90,130,133].

A

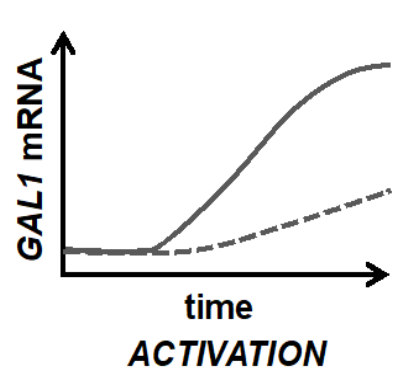

Memory after previous Gal stimulus
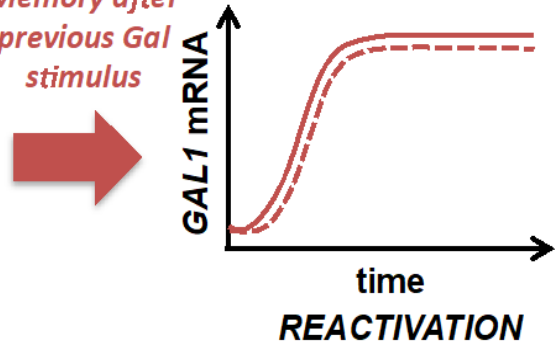

-- low gal

- high gal

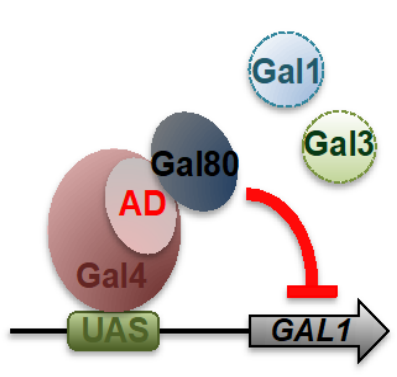

INACTIVE
[Gal]

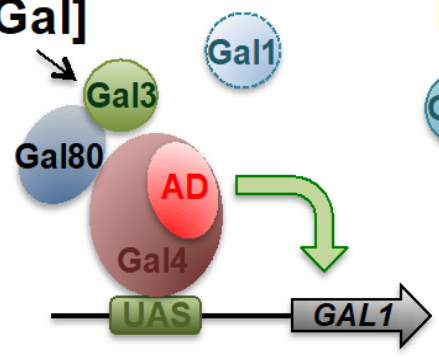

ACTIVE

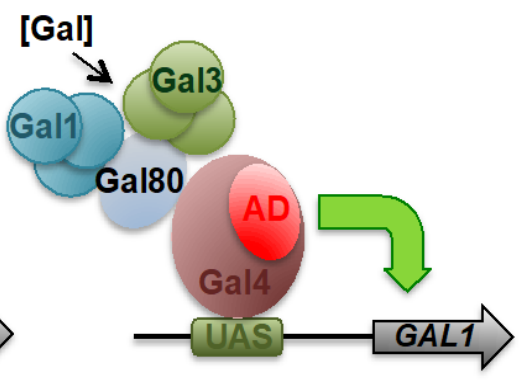

MEMORY

\section{B H3Ac \\ H3K4me 3 \\ H3K4me2}

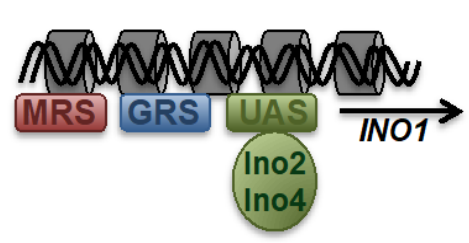

INACTIVE
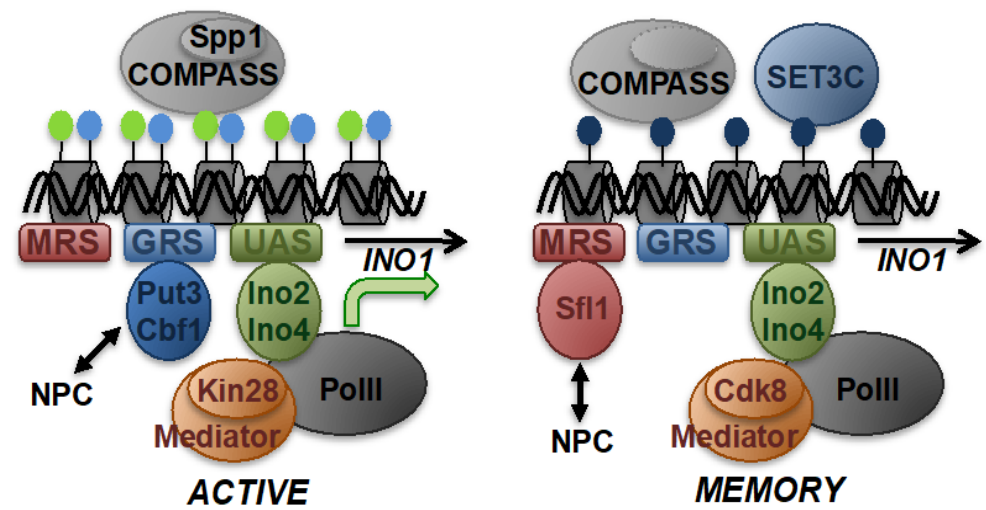

Figure 3. Mechanisms of transcriptional memory. (A) Trans mechanisms of improved reactivation at the GAL1 gene after repeated galactose stimulation. Upper panel: Naïve cells exhibit slow and galactose-insensitive GAL1 activation kinetics. After a previous encounter with galactose, cells respond with a faster, more efficient and sensitive gene induction. Lower panel: Details of transcriptional memory at GAL1 by the reinforcement of signaling. The inactive GAL1 gene is bound by the Gal4 transcriptional activator, which is completely inactivated by association with the Gal80 repressor masking the Gal4 activation domain (AD). A first round of GAL1 transcriptional activation (active) is 
slow and inefficient due to the low amount of the Gal3 galactose sensor and signal transducer. After memory, the previously induced and inherited Gall and Gal3 proteins prepare the experienced cells for fast reactivation even at low galactose doses. Both Gal1 and Gal3 can induce GAL1 expression by Gal80 inhibition. (B) Epigenetic mechanisms of memory at the INO1 gene after repeated inositol starvation. The inactive INO1 gene is characterized by absent histone acetylation or methylation despite Ino2,4 activator binding. A first round of INO1 induction includes the physical anchoring of the gene to the nuclear pore complex (NPC) through binding of Put 3 and Cbf1 to the INO1 gene recruitment sequences (GRS). Histones are modified by acetylation and trimethylation of histone $\mathrm{H} 3$ by the Spp1-containing COMPASS complex. Transcriptionally competent RNA polymerase II is present, accompanied by the Kin28-containing mediator complex. After addition of inositol, the INO1 gene shifts to the memory mode, which is characterized by prolonged NPC anchoring via Sfl1 and the INO1 memory recruitment sequence (MRS), loss of Spp1 from COMPASS, predominant histone H3 dimethylation, binding of the SET3C histone deacetylase complex, and the association of a poised, transcriptionally inactive version of PolII sustained by the Cdk8 module of Mediator. INO1 in the poised chromatin state is reactivated with faster kinetics.

A more pronounced role for chromatin modification and relocalization to the NPC has been found in the case of memory at the INO1 locus (Figure 3). Once activated by a first inositol deprivation, INO1 adopts a memory-specific chromatin configuration characterized by the binding of a specific $\mathrm{TF}$, the persistent translocation to the nuclear envelope, the incorporation of histone variants and histone modifications, and the recruitment of remodeled chromatin-modifying complexes and of a poised PolII complex [122]. The conversion from the activated to the memory state at INO1 is mediated by the binding of the TF Sfl1 to a specific DNA motif in the promoter region, the so-called memory recruitment sequence (MRS) [134]. Both Sfl1 and MRS are necessary to keep INO1 anchored at the nuclear periphery and to maintain several characteristic chromatin features. One feature is histone $\mathrm{H} 3$ dimethylation at lysine 4 (H3K4me2) at the INO1 promoter and coding region [135]. Additionally, the histone variant H2A.Z is specifically incorporated into INO1 chromatin during the memory phase $[128,136]$. H3K4me2 is produced by a remodeled version of the Set1/COMPASS complex lacking the Spp1 subunit necessary for H3K4me3 only during activated INO1 transcription [134]. $\mathrm{H} 3 \mathrm{~K} 4 \mathrm{me} 2$ is then recognized and maintained by the SET3C histone deacetylase complex, which is required to recruit a poised version of PolII to INO1 during memory. PolII assembly during memory is different from PIC formation during normal gene activation, as it recruits PolII in a transcriptionally inactive form. This seems to be assured by PolII assembly in the absence of the Cdk7/Kin28 C-terminal domain (CTD) kinase [134]. Cdk7 promotes promoter escape of the enzyme during normal activation by PolII CTD phosphorylation, which is blocked during INO1 memory. Additionally, Mediator binds as a specific, Cdk8-containing module, which might facilitate maintaining a poised PolII complex at the INO1 locus during memory [134]. Altogether, the INO1 memory mechanism shows that specific genes can adopt a memory configuration after a first stimulation via specific TFs, which is characterized by a combination of histone marks, NPC anchoring, and association of specific chromatin-modifying complexes leading to the permanent binding of PolII in a poised state, thus allowing a faster reactivation of transcription in repeated rounds of stimulation [122,137]. It is important to note that these findings from yeast research reflect several mechanisms conserved for epigenetic memory in higher eukaryotic organisms. Prolonged H3K4me2 is an epigenetic hallmark for memory also for plant and human genes [124,138-140]. Moreover, the persistent binding of a poised, transcriptionally inactive PolII has been found in Caenorhabditis elegans and human cells at some memory genes after previous stimulation $[134,135,141]$.

\section{Gene Expression Heterogeneity in Individual Cells}

Genetically identical cells can show considerable variability in their gene expression patterns, a phenomenon generally called gene expression noise [142]. There are extrinsic and intrinsic factors causing a noisy expression across individual cells. Extrinsic sources of noise are, for example, 
the stochastic initiation of different transcriptional cell fate programs in multicellular organisms in response to gradients of morphogens $[143,144]$. Another example of the extrinsic induction of heterogeneous expression patterns is the response to inflammatory signals in mammalian organisms, where oscillations in NF-KB TFs determine different immune responses and specific cytokine production $[145,146]$. Furthermore, very recently it has been proposed that intrinsic stochasticity of gene expression favors plasticity and robustness of mouse stem cells [147].

Here, we will focus on the establishment and regulation of intrinsic noise of gene expression, which is originated by natural fluctuations of cellular and, especially, intra-nuclear factors or chromatin states $[148,149]$. In microorganisms, the stochastic heterogeneity of gene expression is a mechanism to improve the fitness of a cell population upon unpredicted environmental cues [150-152], in a process which has been coined "bet hedging" [153-155]. Similarly, cancer cell subpopulations with specific chromatin and gene expression variability are sources of drug tolerance during pharmacological treatment [156-158]. It is important to note that, in most cases, the observed heterogeneity is transient and reversible, because it is caused by epigenetic alterations or fluctuations in the activity of proteins critical to the process of gene expression [142,149,159-161].

Pioneering experiments exploring lac repressor regulation by the expression of fluorescent protein markers in bacteria discovered a striking cell-to-cell variability even in this simple regulatory circuit [142]. As a first intrinsic determinant of the observed noise, the abundance of the lac repressor itself was identified [142]. Similar studies in the yeast model using the inducible PHO5 system confirmed gene expression heterogeneity in eukaryotic cells, which is modulated by extrinsic and intrinsic factors [159]. Later genome-wide studies revealed that low expression levels are generally accompanied by high noise, while highly expressed genes are not [162]. Similarly, housekeeping genes are usually more uniformly expressed among cell populations, while environmental stress-responsive genes show a noisier expression pattern [163-165]. This might be explained by the fact that fluctuations of housekeeping proteins is less compatible with essential cell functions as compared to stress-responsive proteins, whose fluctuations might be beneficial for the adaptation to environmental changes [166,167].

Several studies have addressed the question whether transcriptional noise was created by specific cellular or nuclear processes. Promoter engineering in bacteria has shown that variations in the intrinsic promoter design modulates the degree of noise [168], which suggests that altered affinity of TFs is a main source of transcriptional variability [169-171]. Indeed, the TF resources of a cell seem to be critical for noise determination, which increases with limited amount of active TF [172]. Recent studies point to the importance of different bacterial sigma factors in the modulation of transcriptional noise [173]. Studies of the yeast $\mathrm{PHO} 5$ nucleosome positioning further demonstrated that specific chromatin configurations can be an important intrinsic source of transcriptional noise [174,175]. Genome-wide studies in single mammalian cells showed, on a broader scale, that changes in chromatin accessibility generally control transcript variability [176]. Specific histone marks such as H3K79 methylation have been furthermore shown to determine the level of expression noise [177]. Additionally, Drosophila genes with pre-bound, paused RNA PolII have been associated with a more uniform expression pattern, while disruption of PolII pausing increased the stochasticity of gene expression [178]. Transcriptional variability can furthermore be modulated by more physiological characteristics of the cell such as the cell cycle [179] or the process of mRNA export and nuclear compartmentalization, which can have functions in buffering stochastic transcription bursts [180].

It remains an intriguing question whether and how cells are able to regulate general or gene-specific transcription variability according to developmental or environmental changes. It has been determined that noisy gene expression is a complex heritable trait [181]. However, recent work in yeast identified a specific regulator, the methyltransferase Hmt1, as a master regulator of noise [182]. Hmt1 has been proposed to reduce transcriptional variability by methylating strategic effectors with functions in chromatin remodeling (Snf2) or translation (Rps2). Environmental stress could inactivate this pathway and increase cell-to-cell variability in order to better adapt to adverse conditions [182]. 


\section{Conclusions and Future Perspectives}

In the past years, we have witnessed many significant advances in the field of dynamic transcriptional responses. We have successfully moved from a static view of transcription towards a fully dynamic description of gene activation, both at the cell population and at the single-cell level. In fact, any transcriptional regulation cannot be sufficiently understood on the basis of fixed snapshots of the process. Many technical advances, from the continuous monitoring of gene expression by fluorescent and luminescent reporters to the single-cell tracing of TF binding, nascent mRNAs, and chromatin remodeling at single loci, have largely increased the resolution with which we are able to look at specific dynamic features of gene activation processes. TF dynamics and recycling, as well as specific chromatin remodeling have emerged from those studies as modulators of dynamic gene expression. A main future challenge, however, will be to link dynamic transcriptional readouts with higher-order determinants, such as nucleosomal or chromosomal topology and arrangement. Additionally, the great variety of changes in gene expression dynamics must have fundamental biological functions, which in many cases are not well known. For example, it will be important to reveal the molecular drivers of the loss of dynamic gene activation in aged cells, if and how transcriptional dynamics and memory change during adaptation to specific environments or during evolution, or how modulation of transcriptional heterogeneity is achieved and possibly impacts on adaptation and fitness of the cell.

Funding: This work was funded by Ministerio de Ciencia, Innovación y Universidades, grant number BFU2016-75792-R.

Acknowledgments: We apologize to all researchers whose work on related topics was not cited here due to space limitations.

Conflicts of Interest: The authors declare no conflict of interest.

\section{Abbreviations}

$\begin{array}{ll}\text { TF } & \text { Transcription factor } \\ \text { PolII } & \text { RNA polymerase II } \\ \text { ChIP } & \text { Chromatin immunoprecipitation } \\ \text { GFP } & \text { Green fluorescent protein } \\ \text { NPC } & \text { Nuclear pore complex } \\ \text { PIC } & \text { Preinitiation complex } \\ \text { MRS } & \text { Memory recruitment sequence } \\ \text { GRS } & \text { Gene recruitment sequence } \\ \text { AD } & \text { Activation domain } \\ \text { DR } & \text { Dose-response } \\ \text { SAPK } & \text { Stress-activated protein kinase } \\ \text { CTD } & \text { C-terminal domain }\end{array}$

\section{References}

1. Murray, J.I.; Whitfield, M.L.; Trinklein, N.D.; Myers, R.M.; Brown, P.O.; Botstein, D. Diverse and specific gene expression responses to stresses in cultured human cells. Mol. Biol. Cell 2004, 15, 2361-2374. [CrossRef]

2. Gasch, A.P.; Spellman, P.T.; Kao, C.M.; Carmel-Harel, O.; Eisen, M.B.; Storz, G.; Botstein, D.; Brown, P.O. Genomic expression programs in the response of yeast cells to environmental changes. Mol. Biol. Cell 2000, 11, 4241-4257. [CrossRef]

3. Ben-Tabou de-Leon, S.; Davidson, E.H. Gene regulation: Gene control network in development. Annu. Rev. Biophys. Biomol. Struct. 2007, 36, 191-212. [CrossRef]

4. Lenstra, T.L.; Rodriguez, J.; Chen, H.; Larson, D.R. Transcription dynamics in living cells. Annu. Rev. Biophys. 2016, 45, 25-47. [CrossRef]

5. Coulon, A.; Chow, C.C.; Singer, R.H.; Larson, D.R. Eukaryotic transcriptional dynamics: From single molecules to cell populations. Nat. Rev. Genet. 2013, 14, 572-584. [CrossRef] [PubMed] 
6. Yosef, N.; Regev, A. Impulse control: Temporal dynamics in gene transcription. Cell 2011, 144, $886-896$. [CrossRef]

7. Purvis, J.E.; Lahav, G. Encoding and decoding cellular information through signaling dynamics. Cell 2013, 152, 945-956. [CrossRef]

8. Weake, V.M.; Workman, J.L. Inducible gene expression: Diverse regulatory mechanisms. Nat. Rev. Genet. 2010, 11, 426-437. [CrossRef]

9. de Nadal, E.; Ammerer, G.; Posas, F. Controlling gene expression in response to stress. Nat. Rev. Genet. 2011, 12, 833-845. [CrossRef]

10. Vihervaara, A.; Duarte, F.M.; Lis, J.T. Molecular mechanisms driving transcriptional stress responses. Nat. Rev. Genet. 2018, 19, 385-397. [CrossRef]

11. Pérez-Ortín, J.E.; Alepuz, P.; Chávez, S.; Choder, M. Eukaryotic mRNA decay: Methodologies, pathways, and links to other stages of gene expression. J. Mol. Biol. 2013, 425, 3750-3775. [CrossRef]

12. Aparicio, O.; Geisberg, J.V.; Sekinger, E.; Yang, A.; Moqtaderi, Z.; Struhl, K. Chromatin immunoprecipitation for determining the association of proteins with specific genomic sequences in vivo. Curr. Protoc. Mol. Biol. 2005, 69, 21.3.1-21.3.33. [CrossRef]

13. wa Maina, C.; Honkela, A.; Matarese, F.; Grote, K.; Stunnenberg, H.G.; Reid, G.; Lawrence, N.D.; Rattray, M. Inference of RNA polymerase II transcription dynamics from chromatin immunoprecipitation time course data. PLoS Comput. Biol. 2014, 10, e1003598. [CrossRef] [PubMed]

14. Mason, P.B.; Struhl, K. Distinction and relationship between elongation rate and processivity of RNA polymerase II in vivo. Mol. Cell 2005, 17, 831-840. [CrossRef]

15. Sato, H.; Das, S.; Singer, R.H.; Vera, M. Imaging of DNA and RNA in living eukaryotic cells to reveal spatiotemporal dynamics of gene expression. Annu. Rev. Biochem. 2020, 89, 159-187. [CrossRef]

16. Janicki, S.M.; Tsukamoto, T.; Salghetti, S.E.; Tansey, W.P.; Sachidanandam, R.; Prasanth, K.V.; Ried, T.; Shav-Tal, Y.; Bertrand, E.; Singer, R.H.; et al. From silencing to gene expression: Real-time analysis in single cells. Cell 2004, 116, 683-698. [CrossRef]

17. Chao, J.A.; Patskovsky, Y.; Almo, S.C.; Singer, R.H. Structural basis for the coevolution of a viral RNA-protein complex. Nat. Struct. Mol. Biol. 2008, 15, 103-105. [CrossRef]

18. Bertrand, E.; Chartrand, P.; Schaefer, M.; Shenoy, S.M.; Singer, R.H.; Long, R.M. Localization of ASH1 mRNA particles in living yeast. Mol. Cell 1998, 2, 437-445. [CrossRef]

19. Campbell, P.D.; Chao, J.A.; Singer, R.H.; Marlow, F.L. Dynamic visualization of transcription and RNA subcellular localization in zebrafish. Development 2015, 142, 1368-1374. [CrossRef] [PubMed]

20. Golding, I.; Paulsson, J.; Zawilski, S.M.; Cox, E.C. Real-time kinetics of gene activity in individual bacteria. Cell 2005, 123, 1025-1036. [CrossRef] [PubMed]

21. Larson, D.R.; Zenklusen, D.; Wu, B.; Chao, J.A.; Singer, R.H. Real-time observation of transcription initiation and elongation on an endogenous yeast gene. Science 2011, 332, 475-478. [CrossRef]

22. Chubb, J.R.; Trcek, T.; Shenoy, S.M.; Singer, R.H. Transcriptional pulsing of a developmental gene. Curr. Biol. 2006, 16, 1018-1025. [CrossRef]

23. Garcia, H.G.; Tikhonov, M.; Lin, A.; Gregor, T. Quantitative imaging of transcription in living Drosophila embryos links polymerase activity to patterning. Curr. Biol. 2013, 23, 2140-2145. [CrossRef]

24. Xu, H.; Wang, J.; Liang, Y.; Fu, Y.; Li, S.; Huang, J.; Xu, H.; Zou, W.; Chen, B. TriTag: An integrative tool to correlate chromatin dynamics and gene expression in living cells. Nucleic Acids Res. 2020. [CrossRef]

25. Niedenthal, R.K.; Riles, L.; Johnston, M.; Hegemann, J.H. Green fluorescent protein as a marker for gene expression and subcellular localization in budding yeast. Yeast 1996, 12, 773-786. [CrossRef]

26. Plautz, J.D.; Day, R.N.; Dailey, G.M.; Welsh, S.B.; Hall, J.C.; Halpain, S.; Kay, S.A. Green fluorescent protein and its derivatives as versatile markers for gene expression in living Drosophila melanogaster, plant and mammalian cells. Gene 1996, 173, 83-87. [CrossRef]

27. Chalfie, M.; Tu, Y.; Euskirchen, G.; Ward, W.W.; Prasher, D.C. Green fluorescent protein as a marker for gene expression. Science 1994, 263, 802-805. [CrossRef] [PubMed]

28. Bongaerts, R.J.M.; Hautefort, I.; Sidebotham, J.M.; Hinton, J.C.D. Green fluorescent protein as a marker for conditional gene expression in bacterial cells. In Bacterial Pathogenesis Part C: Identification, Regulation, and Function of Virulence Factors; Methods in Enzymology; Elsevier: Amsterdam, The Netherlands, 2002; Volume 358, pp. 43-66. ISBN 9780121822613.

29. Longo, D.; Hasty, J. Dynamics of single-cell gene expression. Mol. Syst. Biol. 2006, 2, 64. [CrossRef] 
30. Zou, F.; Bai, L. Using time-lapse fluorescence microscopy to study gene regulation. Methods 2019, 159-160, 138-145. [CrossRef]

31. Han, J.; Xia, A.; Huang, Y.; Ni, L.; Chen, W.; Jin, Z.; Yang, S.; Jin, F. Simultaneous visualization of multiple gene expression in single cells using an engineered multicolor reporter toolbox and approach of spectral crosstalk correction. ACS Synth. Biol. 2019, 8, 2536-2546. [CrossRef]

32. Mateus, C.; Avery, S.V. Destabilized green fluorescent protein for monitoring dynamic changes in yeast gene expression with flow cytometry. Yeast 2000, 16, 1313-1323. [CrossRef]

33. Li, X.; Zhao, X.; Fang, Y.; Jiang, X.; Duong, T.; Fan, C.; Huang, C.C.; Kain, S.R. Generation of destabilized green fluorescent protein as a transcription reporter. J. Biol. Chem. 1998, 273, 34970-34975. [CrossRef]

34. Andersen, J.B.; Sternberg, C.; Poulsen, L.K.; Bjorn, S.P.; Givskov, M.; Molin, S. New unstable variants of green fluorescent protein for studies of transient gene expression in bacteria. Appl. Environ. Microbiol. 1998, 64, 2240-2246. [CrossRef]

35. He, L.; Binari, R.; Huang, J.; Falo-Sanjuan, J.; Perrimon, N. In vivo study of gene expression with an enhanced dual-color fluorescent transcriptional timer. eLife 2019, 8. [CrossRef]

36. Allen, M.S.; Wilgus, J.R.; Chewning, C.S.; Sayler, G.S.; Simpson, M.L. A destabilized bacterial luciferase for dynamic gene expression studies. Syst. Synth. Biol. 2007, 1, 3-9. [CrossRef]

37. Yasunaga, M.; Murotomi, K.; Abe, H.; Yamazaki, T.; Nishii, S.; Ohbayashi, T.; Oshimura, M.; Noguchi, T.; Niwa, K.; Ohmiya, Y.; et al. Highly sensitive luciferase reporter assay using a potent destabilization sequence of calpain 3. J. Biotechnol. 2015, 194, 115-123. [CrossRef]

38. Leclerc, G.M.; Boockfor, F.R.; Faught, W.J.; Frawley, L.S. Development of a destabilized firefly luciferase enzyme for measurement of gene expression. BioTechniques 2000, 29, 590-591, 594. [CrossRef] [PubMed]

39. Rienzo, A.; Pascual-Ahuir, A.; Proft, M. The use of a real-time luciferase assay to quantify gene expression dynamics in the living yeast cell. Yeast 2012, 29, 219-231. [CrossRef]

40. Robertson, J.B.; Stowers, C.C.; Boczko, E.; Johnson, C.H. Real-time luminescence monitoring of cell-cycle and respiratory oscillations in yeast. Proc. Natl. Acad. Sci. USA 2008, 105, 17988-17993. [CrossRef]

41. Deng, L.; Sugiura, R.; Takeuchi, M.; Suzuki, M.; Ebina, H.; Takami, T.; Koike, A.; Iba, S.; Kuno, T. Real-time monitoring of calcineurin activity in living cells: Evidence for two distinct $\mathrm{Ca}^{2+}$-dependent pathways in fission yeast. Mol. Biol. Cell 2006, 17, 4790-4800. [CrossRef] [PubMed]

42. Mazo-Vargas, A.; Park, H.; Aydin, M.; Buchler, N.E. Measuring fast gene dynamics in single cells with time-lapse luminescence microscopy. Mol. Biol. Cell 2014, 25, 3699-3708. [CrossRef] [PubMed]

43. Liu, Z.; Tjian, R. Visualizing transcription factor dynamics in living cells. J. Cell Biol. 2018, 217, 1181-1191. [CrossRef]

44. Jin, X.; Hapsari, N.D.; Lee, S.; Jo, K. DNA binding fluorescent proteins as single-molecule probes. Analyst 2020, 145, 4079-4095. [CrossRef] [PubMed]

45. Dolz-Edo, L.; Rienzo, A.; Poveda-Huertes, D.; Pascual-Ahuir, A.; Proft, M. Deciphering dynamic dose responses of natural promoters and single cis elements upon osmotic and oxidative stress in yeast. Mol. Cell. Biol. 2013, 33, 2228-2240. [CrossRef]

46. Pascual-Ahuir, A.; González-Cantó, E.; Juyoux, P.; Pable, J.; Poveda-Huertes, D.; Saiz-Balbastre, S.; Squeo, S.; Ureña-Marco, A.; Vanacloig-Pedros, E.; Zaragoza-Infante, L.; et al. Dose dependent gene expression is dynamically modulated by the history, physiology and age of yeast cells. Biochim. Biophys. Acta Gene Regul. Mech. 2019, 1862, 457-471. [CrossRef]

47. Pelet, S.; Rudolf, F.; Nadal-Ribelles, M.; de Nadal, E.; Posas, F.; Peter, M. Transient activation of the HOG MAPK pathway regulates bimodal gene expression. Science 2011, 332, 732-735. [CrossRef]

48. Paliwal, S.; Iglesias, P.A.; Campbell, K.; Hilioti, Z.; Groisman, A.; Levchenko, A. MAPK-mediated bimodal gene expression and adaptive gradient sensing in yeast. Nature 2007, 446, 46-51. [CrossRef]

49. Zhang, Q.; Yoon, Y.; Yu, Y.; Parnell, E.J.; Garay, J.A.R.; Mwangi, M.M.; Cross, F.R.; Stillman, D.J.; Bai, L. Stochastic expression and epigenetic memory at the yeast HO promoter. Proc. Natl. Acad. Sci. USA 2013, 110, 14012-14017. [CrossRef] [PubMed]

50. Gutin, J.; Joseph-Strauss, D.; Sadeh, A.; Shalom, E.; Friedman, N. Genetic screen of the yeast environmental stress response dynamics uncovers distinct regulatory phases. Mol. Syst. Biol. 2019, 15, e8939. [CrossRef]

51. Rajkumar, A.S.; Liu, G.; Bergenholm, D.; Arsovska, D.; Kristensen, M.; Nielsen, J.; Jensen, M.K.; Keasling, J.D. Engineering of synthetic, stress-responsive yeast promoters. Nucleic Acids Res. 2016, 44, e136. [CrossRef] 
52. Duveau, F.; Yuan, D.C.; Metzger, B.P.H.; Hodgins-Davis, A.; Wittkopp, P.J. Effects of mutation and selection on plasticity of a promoter activity in Saccharomyces cerevisiae. Proc. Natl. Acad. Sci. USA 2017, 114, E11218-E11227. [CrossRef]

53. Redden, H.; Morse, N.; Alper, H.S. The synthetic biology toolbox for tuning gene expression in yeast. FEMS Yeast Res. 2015, 15, 1-10. [CrossRef]

54. Brouwer, I.; Lenstra, T.L. Visualizing transcription: Key to understanding gene expression dynamics. Curr. Opin. Chem. Biol. 2019, 51, 122-129. [CrossRef]

55. Rodriguez, J.; Larson, D.R. Transcription in living cells: Molecular mechanisms of bursting. Annu. Rev. Biochem. 2020, 89, 189-212. [CrossRef]

56. Tunnacliffe, E.; Chubb, J.R. What is a transcriptional burst? Trends Genet. 2020, 36, 288-297. [CrossRef] [PubMed]

57. Hornung, G.; Bar-Ziv, R.; Rosin, D.; Tokuriki, N.; Tawfik, D.S.; Oren, M.; Barkai, N. Noise-mean relationship in mutated promoters. Genome Res. 2012, 22, 2409-2417. [CrossRef]

58. Dadiani, M.; van Dijk, D.; Segal, B.; Field, Y.; Ben-Artzi, G.; Raveh-Sadka, T.; Levo, M.; Kaplow, I.; Weinberger, A.; Segal, E. Two DNA-encoded strategies for increasing expression with opposing effects on promoter dynamics and transcriptional noise. Genome Res. 2013, 23, 966-976. [CrossRef]

59. Raveh-Sadka, T.; Levo, M.; Shabi, U.; Shany, B.; Keren, L.; Lotan-Pompan, M.; Zeevi, D.; Sharon, E.; Weinberger, A.; Segal, E. Manipulating nucleosome disfavoring sequences allows fine-tune regulation of gene expression in yeast. Nat. Genet. 2012, 44,743-750. [CrossRef]

60. van Dijk, D.; Sharon, E.; Lotan-Pompan, M.; Weinberger, A.; Segal, E.; Carey, L.B. Large-scale mapping of gene regulatory logic reveals context-dependent repression by transcriptional activators. Genome Res. 2017, 27, 87-94. [CrossRef]

61. Mehta, G.D.; Ball, D.A.; Eriksson, P.R.; Chereji, R.V.; Clark, D.J.; McNally, J.G.; Karpova, T.S. Single-Molecule Analysis Reveals Linked Cycles of RSC Chromatin Remodeling and Ace1p Transcription Factor Binding in Yeast. Mol. Cell 2018, 72, 875-887.e9. [CrossRef] [PubMed]

62. Ball, D.A.; Mehta, G.D.; Salomon-Kent, R.; Mazza, D.; Morisaki, T.; Mueller, F.; McNally, J.G.; Karpova, T.S. Single molecule tracking of Ace1p in Saccharomyces cerevisiae defines a characteristic residence time for non-specific interactions of transcription factors with chromatin. Nucleic Acids Res. 2016, 44, e160. [CrossRef]

63. Karpova, T.S.; Kim, M.J.; Spriet, C.; Nalley, K.; Stasevich, T.J.; Kherrouche, Z.; Heliot, L.; McNally, J.G. Concurrent fast and slow cycling of a transcriptional activator at an endogenous promoter. Science 2008, 319, 466-469. [CrossRef] [PubMed]

64. Donovan, B.T.; Huynh, A.; Ball, D.A.; Patel, H.P.; Poirier, M.G.; Larson, D.R.; Ferguson, M.L.; Lenstra, T.L. Live-cell imaging reveals the interplay between transcription factors, nucleosomes, and bursting. EMBO J. 2019, 38. [CrossRef]

65. Lenstra, T.L.; Coulon, A.; Chow, C.C.; Larson, D.R. Single-Molecule Imaging Reveals a Switch between Spurious and Functional ncRNA Transcription. Mol. Cell 2015, 60, 597-610. [CrossRef] [PubMed]

66. Senecal, A.; Munsky, B.; Proux, F.; Ly, N.; Braye, F.E.; Zimmer, C.; Mueller, F.; Darzacq, X. Transcription factors modulate c-Fos transcriptional bursts. Cell Rep. 2014, 8, 75-83. [CrossRef]

67. Stavreva, D.A.; Garcia, D.A.; Fettweis, G.; Gudla, P.R.; Zaki, G.F.; Soni, V.; McGowan, A.; Williams, G.; Huynh, A.; Palangat, M.; et al. Transcriptional Bursting and Co-bursting Regulation by Steroid Hormone Release Pattern and Transcription Factor Mobility. Mol. Cell 2019, 75, 1161-1177.e11. [CrossRef]

68. Nelson, D.E.; Ihekwaba, A.E.C.; Elliott, M.; Johnson, J.R.; Gibney, C.A.; Foreman, B.E.; Nelson, G.; See, V.; Horton, C.A.; Spiller, D.G.; et al. Oscillations in NF-kappaB signaling control the dynamics of gene expression. Science 2004, 306, 704-708. [CrossRef] [PubMed]

69. Lahav, G.; Rosenfeld, N.; Sigal, A.; Geva-Zatorsky, N.; Levine, A.J.; Elowitz, M.B.; Alon, U. Dynamics of the p53-Mdm2 feedback loop in individual cells. Nat. Genet. 2004, 36, 147-150. [CrossRef]

70. Izeddin, I.; Récamier, V.; Bosanac, L.; Cissé, I.I.; Boudarene, L.; Dugast-Darzacq, C.; Proux, F.; Bénichou, O.; Voituriez, R.; Bensaude, O.; et al. Single-molecule tracking in live cells reveals distinct target-search strategies of transcription factors in the nucleus. ELife 2014, 3. [CrossRef] [PubMed]

71. Suter, D.M.; Molina, N.; Gatfield, D.; Schneider, K.; Schibler, U.; Naef, F. Mammalian genes are transcribed with widely different bursting kinetics. Science 2011, 332, 472-474. [CrossRef]

72. Keller, S.H.; Jena, S.G.; Yamazaki, Y.; Lim, B. Regulation of spatiotemporal limits of developmental gene expression via enhancer grammar. Proc. Natl. Acad. Sci. USA 2020, 117, 15096-15103. [CrossRef] [PubMed] 
73. Ochiai, H.; Hayashi, T.; Umeda, M.; Yoshimura, M.; Harada, A.; Shimizu, Y.; Nakano, K.; Saitoh, N.; Liu, Z.; Yamamoto, T.; et al. Genome-wide kinetic properties of transcriptional bursting in mouse embryonic stem cells. Sci. Adv. 2020, 6, eaaz6699. [CrossRef] [PubMed]

74. Hoppe, C.; Bowles, J.R.; Minchington, T.G.; Sutcliffe, C.; Upadhyai, P.; Rattray, M.; Ashe, H.L. Modulation of the promoter activation rate dictates the transcriptional response to graded BMP signaling levels in the drosophila embryo. Dev. Cell 2020, 54, 727-741.e7. [CrossRef]

75. Bakker, R.; Mani, M.; Carthew, R.W. The Wg and Dpp morphogens regulate gene expression by modulating the frequency of transcriptional bursts. Elife 2020, 9. [CrossRef]

76. Klemm, S.L.; Shipony, Z.; Greenleaf, W.J. Chromatin accessibility and the regulatory epigenome. Nat. Rev. Genet. 2019, 20, 207-220. [CrossRef]

77. Nocetti, N.; Whitehouse, I. Nucleosome repositioning underlies dynamic gene expression. Genes Dev. 2016, 30, 660-672. [CrossRef]

78. Cosma, M.P.; Tanaka, T.; Nasmyth, K. Ordered recruitment of transcription and chromatin remodeling factors to a cell cycle- and developmentally regulated promoter. Cell 1999, 97, 299-311. [CrossRef]

79. Govind, C.K.; Yoon, S.; Qiu, H.; Govind, S.; Hinnebusch, A.G. Simultaneous recruitment of coactivators by Gcn4p stimulates multiple steps of transcription in vivo. Mol. Cell. Biol. 2005, 25, 5626-5638. [CrossRef]

80. Biggar, S.R.; Crabtree, G.R. Continuous and widespread roles for the Swi-Snf complex in transcription. EMBO J. 1999, 18, 2254-2264. [CrossRef] [PubMed]

81. Rando, O.J.; Winston, F. Chromatin and transcription in yeast. Genetics 2012, 190, 351-387. [CrossRef]

82. Shen, C.H.; Leblanc, B.P.; Alfieri, J.A.; Clark, D.J. Remodeling of yeast CUP1 chromatin involves activator-dependent repositioning of nucleosomes over the entire gene and flanking sequences. Mol. Cell. Biol. 2001, 21, 534-547. [CrossRef]

83. Shen, C.H.; Clark, D.J. DNA sequence plays a major role in determining nucleosome positions in yeast CUP1 chromatin. J. Biol. Chem. 2001, 276, 35209-35216. [CrossRef]

84. Erkina, T.Y.; Zou, Y.; Freeling, S.; Vorobyev, V.I.; Erkine, A.M. Functional interplay between chromatin remodeling complexes RSC, SWI/SNF and ISWI in regulation of yeast heat shock genes. Nucleic Acids Res. 2010, 38, 1441-1449. [CrossRef] [PubMed]

85. Mitra, D.; Parnell, E.J.; Landon, J.W.; Yu, Y.; Stillman, D.J. SWI/SNF binding to the HO promoter requires histone acetylation and stimulates TATA-binding protein recruitment. Mol. Cell. Biol. 2006, 26, 4095-4110. [CrossRef]

86. Sudarsanam, P.; Cao, Y.; Wu, L.; Laurent, B.C.; Winston, F. The nucleosome remodeling complex, Snf/Swi, is required for the maintenance of transcription in vivo and is partially redundant with the histone acetyltransferase, Gcn5. EMBO J. 1999, 18, 3101-3106. [CrossRef] [PubMed]

87. Barbaric, S.; Luckenbach, T.; Schmid, A.; Blaschke, D.; Hörz, W.; Korber, P. Redundancy of chromatin remodeling pathways for the induction of the yeast PHO5 promoter in vivo. J. Biol. Chem. 2007, 282, 27610-27621. [CrossRef]

88. Proft, M.; Struhl, K. Hog1 kinase converts the Sko1-Cyc8-Tup1 repressor complex into an activator that recruits SAGA and SWI/SNF in response to osmotic stress. Mol. Cell 2002, 9, 1307-1317. [CrossRef]

89. Lemieux, K.; Gaudreau, L. Targeting of Swi/Snf to the yeast GAL1 UAS G requires the Mediator, TAF IIs, and RNA polymerase II. EMBO J. 2004, 23, 4040-4050. [CrossRef]

90. Rienzo, A.; Poveda-Huertes, D.; Aydin, S.; Buchler, N.E.; Pascual-Ahuir, A.; Proft, M. Different Mechanisms Confer Gradual Control and Memory at Nutrient- and Stress-Regulated Genes in Yeast. Mol. Cell. Biol. 2015, 35, 3669-3683. [CrossRef]

91. Kundu, S.; Horn, P.J.; Peterson, C.L. SWI/SNF is required for transcriptional memory at the yeast GAL gene cluster. Genes Dev. 2007, 21, 997-1004. [CrossRef]

92. Dhasarathy, A.; Kladde, M.P. Promoter occupancy is a major determinant of chromatin remodeling enzyme requirements. Mol. Cell. Biol. 2005, 25, 2698-2707. [CrossRef] [PubMed]

93. Acar, M.; Becskei, A.; van Oudenaarden, A. Enhancement of cellular memory by reducing stochastic transitions. Nature 2005, 435, 228-232. [CrossRef]

94. Vanacloig-Pedros, E.; Lozano-Pérez, C.; Alarcón, B.; Pascual-Ahuir, A.; Proft, M. Live-cell assays reveal selectivity and sensitivity of the multidrug response in budding yeast. J. Biol. Chem. 2019, 294, 12933-12946. [CrossRef] 
95. Thakur, J.K.; Arthanari, H.; Yang, F.; Pan, S.-J.; Fan, X.; Breger, J.; Frueh, D.P.; Gulshan, K.; Li, D.K.; Mylonakis, E.; et al. A nuclear receptor-like pathway regulating multidrug resistance in fungi. Nature 2008, 452, 604-609. [CrossRef] [PubMed]

96. Hao, N.; Budnik, B.A.; Gunawardena, J.; O'Shea, E.K. Tunable signal processing through modular control of transcription factor translocation. Science 2013, 339, 460-464. [CrossRef]

97. Hansen, A.S.; O'Shea, E.K. Encoding four gene expression programs in the activation dynamics of a single transcription factor. Curr. Biol. 2016, 26, R269-R271. [CrossRef] [PubMed]

98. Hao, N.; O'Shea, E.K. Signal-dependent dynamics of transcription factor translocation controls gene expression. Nat. Struct. Mol. Biol. 2011, 19, 31-39. [CrossRef]

99. Babazadeh, R.; Lahtvee, P.-J.; Adiels, C.B.; Goksör, M.; Nielsen, J.B.; Hohmann, S. The yeast osmostress response is carbon source dependent. Sci. Rep. 2017, 7, 990. [CrossRef]

100. Vanacloig-Pedros, E.; Bets-Plasencia, C.; Pascual-Ahuir, A.; Proft, M. Coordinated gene regulation in the initial phase of salt stress adaptation. J. Biol. Chem. 2015, 290, 10163-10175. [CrossRef]

101. Nikopoulou, C.; Parekh, S.; Tessarz, P. Ageing and sources of transcriptional heterogeneity. Biol. Chem. 2019, 400, 867-878. [CrossRef]

102. Feser, J.; Truong, D.; Das, C.; Carson, J.J.; Kieft, J.; Harkness, T.; Tyler, J.K. Elevated histone expression promotes life span extension. Mol. Cell 2010, 39, 724-735. [CrossRef]

103. Hu, Z.; Chen, K.; Xia, Z.; Chavez, M.; Pal, S.; Seol, J.-H.; Chen, C.-C.; Li, W.; Tyler, J.K. Nucleosome loss leads to global transcriptional up-regulation and genomic instability during yeast aging. Genes Dev. 2014, 28, 396-408. [CrossRef] [PubMed]

104. Sen, P.; Dang, W.; Donahue, G.; Dai, J.; Dorsey, J.; Cao, X.; Liu, W.; Cao, K.; Perry, R.; Lee, J.Y.; et al. H3K36 methylation promotes longevity by enhancing transcriptional fidelity. Genes Dev. 2015, 29, 1362-1376. [CrossRef]

105. Feser, J.; Tyler, J. Chromatin structure as a mediator of aging. FEBS Lett. 2011, 585, 2041-2048. [CrossRef]

106. Liu, P.; Song, R.; Elison, G.L.; Peng, W.; Acar, M. Noise reduction as an emergent property of single-cell aging. Nat. Commun. 2017, 8, 680. [CrossRef]

107. Işıldak, U.; Somel, M.; Thornton, J.M.; Dönertaş, H.M. Temporal changes in the gene expression heterogeneity during brain development and aging. Sci. Rep. 2020, 10, 4080. [CrossRef]

108. Wiley, C.D.; Flynn, J.M.; Morrissey, C.; Lebofsky, R.; Shuga, J.; Dong, X.; Unger, M.A.; Vijg, J.; Melov, S.; Campisi, J. Analysis of individual cells identifies cell-to-cell variability following induction of cellular senescence. Aging Cell 2017, 16, 1043-1050. [CrossRef] [PubMed]

109. Enge, M.; Arda, H.E.; Mignardi, M.; Beausang, J.; Bottino, R.; Kim, S.K.; Quake, S.R. Single-Cell Analysis of Human Pancreas Reveals Transcriptional Signatures of Aging and Somatic Mutation Patterns. Cell 2017, 171, 321-330.e14. [CrossRef]

110. Bahar, R.; Hartmann, C.H.; Rodriguez, K.A.; Denny, A.D.; Busuttil, R.A.; Dollé, M.E.T.; Calder, R.B.; Chisholm, G.B.; Pollock, B.H.; Klein, C.A.; et al. Increased cell-to-cell variation in gene expression in ageing mouse heart. Nature 2006, 441, 1011-1014. [CrossRef] [PubMed]

111. Angelidis, I.; Simon, L.M.; Fernandez, I.E.; Strunz, M.; Mayr, C.H.; Greiffo, F.R.; Tsitsiridis, G.; Ansari, M.; Graf, E.; Strom, T.-M.; et al. An atlas of the aging lung mapped by single cell transcriptomics and deep tissue proteomics. Nat. Commun. 2019, 10, 963. [CrossRef]

112. Koohy, H.; Bolland, D.J.; Matheson, L.S.; Schoenfelder, S.; Stellato, C.; Dimond, A.; Várnai, C.; Chovanec, P.; Chessa, T.; Denizot, J.; et al. Genome organization and chromatin analysis identify transcriptional downregulation of insulin-like growth factor signaling as a hallmark of aging in developing B cells. Genome Biol. 2018, 19, 126. [CrossRef] [PubMed]

113. Bochkis, I.M.; Przybylski, D.; Chen, J.; Regev, A. Changes in nucleosome occupancy associated with metabolic alterations in aged mammalian liver. Cell Rep. 2014, 9, 996-1006. [CrossRef]

114. Ucar, D.; Márquez, E.J.; Chung, C.-H.; Marches, R.; Rossi, R.J.; Uyar, A.; Wu, T.-C.; George, J.; Stitzel, M.L.; Palucka, A.K.; et al. The chromatin accessibility signature of human immune aging stems from CD8+ T cells. J. Exp. Med. 2017, 214, 3123-3144. [CrossRef] [PubMed]

115. Cheung, P.; Vallania, F.; Warsinske, H.C.; Donato, M.; Schaffert, S.; Chang, S.E.; Dvorak, M.; Dekker, C.L.; Davis, M.M.; Utz, P.J.; et al. Single-Cell Chromatin Modification Profiling Reveals Increased Epigenetic Variations with Aging. Cell 2018, 173, 1385-1397.e14. [CrossRef]

116. Booth, L.N.; Brunet, A. The Aging Epigenome. Mol. Cell 2016, 62, 728-744. [CrossRef] [PubMed] 
117. Martinez-Jimenez, C.P.; Eling, N.; Chen, H.-C.; Vallejos, C.A.; Kolodziejczyk, A.A.; Connor, F.; Stojic, L.; Rayner, T.F.; Stubbington, M.J.T.; Teichmann, S.A.; et al. Aging increases cell-to-cell transcriptional variability upon immune stimulation. Science 2017, 355, 1433-1436. [CrossRef]

118. Frenk, S.; Houseley, J. Gene expression hallmarks of cellular ageing. Biogerontology 2018, 19, 547-566. [CrossRef]

119. Riera, C.E.; Merkwirth, C.; De Magalhaes Filho, C.D.; Dillin, A. Signaling networks determining life span. Annu. Rev. Biochem. 2016, 85, 35-64. [CrossRef]

120. Guan, Q.; Haroon, S.; Bravo, D.G.; Will, J.L.; Gasch, A.P. Cellular memory of acquired stress resistance in Saccharomyces cerevisiae. Genetics 2012, 192, 495-505. [CrossRef]

121. Meriem, Z.B.; Khalil, Y.; Hersen, P.; Fabre, E. Hyperosmotic stress response memory is modulated by gene positioning in yeast. Cells 2019, 8, 582. [CrossRef]

122. D’Urso, A.; Brickner, J.H. Epigenetic transcriptional memory. Curr. Genet. 2017, 63, 435-439. [CrossRef]

123. Avramova, Z. Transcriptional "memory" of a stress: Transient chromatin and memory (epigenetic) marks at stress-response genes. Plant J. 2015, 83, 149-159. [CrossRef]

124. Gialitakis, M.; Arampatzi, P.; Makatounakis, T.; Papamatheakis, J. Gamma interferon-dependent transcriptional memory via relocalization of a gene locus to PML nuclear bodies. Mol. Cell. Biol. 2010, 30, 2046-2056. [CrossRef] [PubMed]

125. Ding, Y.; Liu, N.; Virlouvet, L.; Riethoven, J.-J.; Fromm, M.; Avramova, Z. Four distinct types of dehydration stress memory genes in Arabidopsis thaliana. BMC Plant Biol. 2013, 13, 229. [CrossRef]

126. Liu, N.; Ding, Y.; Fromm, M.; Avramova, Z. Different gene-specific mechanisms determine the "revised-response" memory transcription patterns of a subset of $A$. thaliana dehydration stress responding genes. Nucleic Acids Res. 2014, 42, 5556-5566. [CrossRef]

127. Ding, Y.; Fromm, M.; Avramova, Z. Multiple exposures to drought "train" transcriptional responses in Arabidopsis. Nat. Commun. 2012, 3, 740. [CrossRef]

128. Brickner, D.G.; Cajigas, I.; Fondufe-Mittendorf, Y.; Ahmed, S.; Lee, P.-C.; Widom, J.; Brickner, J.H. H2A.Z-mediated localization of genes at the nuclear periphery confers epigenetic memory of previous transcriptional state. PLoS Biol. 2007, 5, e81. [CrossRef] [PubMed]

129. Sood, V.; Cajigas, I.; D’Urso, A.; Light, W.H.; Brickner, J.H. Epigenetic Transcriptional Memory of GAL Genes Depends on Growth in Glucose and the Tup1 Transcription Factor in Saccharomyces cerevisiae. Genetics 2017, 206, 1895-1907. [CrossRef] [PubMed]

130. Kundu, S.; Peterson, C.L. Dominant role for signal transduction in the transcriptional memory of yeast GAL genes. Mol. Cell. Biol. 2010, 30, 2330-2340. [CrossRef]

131. Zacharioudakis, I.; Gligoris, T.; Tzamarias, D. A yeast catabolic enzyme controls transcriptional memory. Curr. Biol. 2007, 17, 2041-2046. [CrossRef] [PubMed]

132. Lavy, T.; Yanagida, H.; Tawfik, D.S. Gal3 Binds Gal80 Tighter than Gal1 Indicating Adaptive Protein Changes Following Duplication. Mol. Biol. Evol. 2016, 33, 472-477. [CrossRef] [PubMed]

133. Sood, V.; Brickner, J.H. Genetic and epigenetic strategies potentiate gal4 activation to enhance fitness in recently diverged yeast species. Curr. Biol. 2017, 27, 3591-3602.e3. [CrossRef]

134. D’Urso, A.; Takahashi, Y.-H.; Xiong, B.; Marone, J.; Coukos, R.; Randise-Hinchliff, C.; Wang, J.-P.; Shilatifard, A.; Brickner, J.H. Set1/COMPASS and Mediator are repurposed to promote epigenetic transcriptional memory. Elife 2016, 5. [CrossRef]

135. Light, W.H.; Freaney, J.; Sood, V.; Thompson, A.; D’Urso, A.; Horvath, C.M.; Brickner, J.H. A conserved role for human Nup98 in altering chromatin structure and promoting epigenetic transcriptional memory. PLoS Biol. 2013, 11, e1001524. [CrossRef]

136. Light, W.H.; Brickner, D.G.; Brand, V.R.; Brickner, J.H. Interaction of a DNA zip code with the nuclear pore complex promotes H2A.Z incorporation and INO1 transcriptional memory. Mol. Cell 2010, 40, 112-125. [CrossRef] [PubMed]

137. Fabrizio, P.; Garvis, S.; Palladino, F. Histone methylation and memory of environmental stress. Cells 2019, 8, 339. [CrossRef]

138. Lämke, J.; Brzezinka, K.; Altmann, S.; Bäurle, I. A hit-and-run heat shock factor governs sustained histone methylation and transcriptional stress memory. EMBO J. 2016, 35, 162-175. [CrossRef] 
139. Bevington, S.L.; Cauchy, P.; Piper, J.; Bertrand, E.; Lalli, N.; Jarvis, R.C.; Gilding, L.N.; Ott, S.; Bonifer, C.; Cockerill, P.N. Inducible chromatin priming is associated with the establishment of immunological memory in T cells. EMBO J. 2016, 35, 515-535. [CrossRef]

140. To, T.K.; Kim, J.M. Epigenetic regulation of gene responsiveness in Arabidopsis. Front. Plant Sci. 2014, 4, 548. [CrossRef]

141. Maxwell, C.S.; Kruesi, W.S.; Core, L.J.; Kurhanewicz, N.; Waters, C.T.; Lewarch, C.L.; Antoshechkin, I.; Lis, J.T.; Meyer, B.J.; Baugh, L.R. Pol II docking and pausing at growth and stress genes in C. elegans. Cell Rep. 2014, 6, 455-466. [CrossRef]

142. Elowitz, M.B.; Levine, A.J.; Siggia, E.D.; Swain, P.S. Stochastic gene expression in a single cell. Science 2002, 297, 1183-1186. [CrossRef] [PubMed]

143. Rogers, K.W.; Schier, A.F. Morphogen gradients: From generation to interpretation. Annu. Rev. Cell Dev. Biol. 2011, 27, 377-407. [CrossRef]

144. Losick, R.; Desplan, C. Stochasticity and cell fate. Science 2008, 320, 65-68. [CrossRef]

145. Natoli, G.; Saccani, S.; Bosisio, D.; Marazzi, I. Interactions of NF-kappaB with chromatin: The art of being at the right place at the right time. Nat. Immunol. 2005, 6, 439-445. [CrossRef]

146. Kellogg, R.A.; Tay, S. Noise facilitates transcriptional control under dynamic inputs. Cell 2015, 160, $381-392$. [CrossRef]

147. Wheat, J.C.; Sella, Y.; Willcockson, M.; Skoultchi, A.I.; Bergman, A.; Singer, R.H.; Steidl, U. Single-molecule imaging of transcription dynamics in somatic stem cells. Nature 2020, 583, 431-436. [CrossRef]

148. Swain, P.S.; Elowitz, M.B.; Siggia, E.D. Intrinsic and extrinsic contributions to stochasticity in gene expression. Proc. Natl. Acad. Sci. USA 2002, 99, 12795-12800. [CrossRef]

149. Kaern, M.; Elston, T.C.; Blake, W.J.; Collins, J.J. Stochasticity in gene expression: From theories to phenotypes. Nat. Rev. Genet. 2005, 6, 451-464. [CrossRef]

150. Acar, M.; Mettetal, J.T.; van Oudenaarden, A. Stochastic switching as a survival strategy in fluctuating environments. Nat. Genet. 2008, 40, 471-475. [CrossRef]

151. Balaban, N.Q.; Merrin, J.; Chait, R.; Kowalik, L.; Leibler, S. Bacterial persistence as a phenotypic switch. Science 2004, 305, 1622-1625. [CrossRef]

152. Schmutzer, M.; Wagner, A. Gene expression noise can promote the fixation of beneficial mutations in fluctuating environments. PLoS Comput. Biol. 2020, 16, e1007727. [CrossRef]

153. Levy, S.F.; Ziv, N.; Siegal, M.L. Bet hedging in yeast by heterogeneous, age-correlated expression of a stress protectant. PLoS Biol. 2012, 10, e1001325. [CrossRef]

154. Levy, S.F. Cellular Heterogeneity: Benefits besides Bet-Hedging. Curr. Biol. 2016, 26, R355-R357. [CrossRef]

155. Gefen, O.; Balaban, N.Q. The importance of being persistent: Heterogeneity of bacterial populations under antibiotic stress. FEMS Microbiol. Rev. 2009, 33, 704-717. [CrossRef]

156. Sharma, S.V.; Lee, D.Y.; Li, B.; Quinlan, M.P.; Takahashi, F.; Maheswaran, S.; McDermott, U.; Azizian, N.; Zou, L.; Fischbach, M.A.; et al. A chromatin-mediated reversible drug-tolerant state in cancer cell subpopulations. Cell 2010, 141, 69-80. [CrossRef]

157. Roesch, A.; Fukunaga-Kalabis, M.; Schmidt, E.C.; Zabierowski, S.E.; Brafford, P.A.; Vultur, A.; Basu, D.; Gimotty, P.; Vogt, T.; Herlyn, M. A temporarily distinct subpopulation of slow-cycling melanoma cells is required for continuous tumor growth. Cell 2010, 141, 583-594. [CrossRef]

158. Shaffer, S.M.; Dunagin, M.C.; Torborg, S.R.; Torre, E.A.; Emert, B.; Krepler, C.; Beqiri, M.; Sproesser, K.; Brafford, P.A.; Xiao, M.; et al. Rare cell variability and drug-induced reprogramming as a mode of cancer drug resistance. Nature 2017, 546, 431-435. [CrossRef]

159. Raser, J.M.; O'Shea, E.K. Control of stochasticity in eukaryotic gene expression. Science 2004, 304, 1811-1814. [CrossRef]

160. Lidstrom, M.E.; Konopka, M.C. The role of physiological heterogeneity in microbial population behavior. Nat. Chem. Biol. 2010, 6, 705-712. [CrossRef]

161. Brown, R.; Curry, E.; Magnani, L.; Wilhelm-Benartzi, C.S.; Borley, J. Poised epigenetic states and acquired drug resistance in cancer. Nat. Rev. Cancer 2014, 14, 747-753. [CrossRef]

162. Bar-Even, A.; Paulsson, J.; Maheshri, N.; Carmi, M.; O'Shea, E.; Pilpel, Y.; Barkai, N. Noise in protein expression scales with natural protein abundance. Nat. Genet. 2006, 38, 636-643. [CrossRef]

163. Barroso, G.V.; Puzovic, N.; Dutheil, J.Y. The Evolution of Gene-Specific Transcriptional Noise Is Driven by Selection at the Pathway Level. Genetics 2018, 208, 173-189. [CrossRef] 
164. Newman, J.R.S.; Ghaemmaghami, S.; Ihmels, J.; Breslow, D.K.; Noble, M.; DeRisi, J.L.; Weissman, J.S. Single-cell proteomic analysis of $S$. cerevisiae reveals the architecture of biological noise. Nature 2006, 441, 840-846. [CrossRef]

165. Gasch, A.P.; Yu, F.B.; Hose, J.; Escalante, L.E.; Place, M.; Bacher, R.; Kanbar, J.; Ciobanu, D.; Sandor, L.; Grigoriev, I.V.; et al. Single-cell RNA sequencing reveals intrinsic and extrinsic regulatory heterogeneity in yeast responding to stress. PLoS Biol. 2017, 15, e2004050. [CrossRef]

166. Charlebois, D.A.; Abdennur, N.; Kaern, M. Gene expression noise facilitates adaptation and drug resistance independently of mutation. Phys. Rev. Lett. 2011, 107, 218101. [CrossRef]

167. Charlebois, D.A. Effect and evolution of gene expression noise on the fitness landscape. Phys. Rev. E Stat. Nonlinear Soft Matter Phys. 2015, 92, 022713. [CrossRef]

168. Jones, D.L.; Brewster, R.C.; Phillips, R. Promoter architecture dictates cell-to-cell variability in gene expression. Science 2014, 346, 1533-1536. [CrossRef]

169. Sanchez, A.; Golding, I. Genetic determinants and cellular constraints in noisy gene expression. Science 2013, 342, 1188-1193. [CrossRef]

170. Sanchez, A.; Choubey, S.; Kondev, J. Regulation of noise in gene expression. Annu. Rev. Biophys. 2013, 42, 469-491. [CrossRef]

171. Sánchez, A.; Kondev, J. Transcriptional control of noise in gene expression. Proc. Natl. Acad. Sci. USA 2008, 105, 5081-5086. [CrossRef]

172. Das, D.; Dey, S.; Brewster, R.C.; Choubey, S. Effect of transcription factor resource sharing on gene expression noise. PLoS Comput. Biol. 2017, 13, e1005491. [CrossRef]

173. Engl, C.; Jovanovic, G.; Brackston, R.D.; Kotta-Loizou, I.; Buck, M. The route to transcription initiation determines the mode of transcriptional bursting in E. coli. Nat. Commun. 2020, 11, 2422. [CrossRef]

174. Brown, C.R.; Boeger, H. Nucleosomal promoter variation generates gene expression noise. Proc. Natl. Acad. Sci. USA 2014, 111, 17893-17898. [CrossRef]

175. Brown, C.R.; Mao, C.; Falkovskaia, E.; Jurica, M.S.; Boeger, H. Linking stochastic fluctuations in chromatin structure and gene expression. PLoS Biol. 2013, 11, e1001621. [CrossRef]

176. Buenrostro, J.D.; Wu, B.; Litzenburger, U.M.; Ruff, D.; Gonzales, M.L.; Snyder, M.P.; Chang, H.Y.; Greenleaf, W.J. Single-cell chromatin accessibility reveals principles of regulatory variation. Nature 2015, 523, 486-490. [CrossRef]

177. Wu, S.; Li, K.; Li, Y.; Zhao, T.; Li, T.; Yang, Y.-F.; Qian, W. Independent regulation of gene expression level and noise by histone modifications. PLoS Comput. Biol. 2017, 13, e1005585. [CrossRef]

178. Lagha, M.; Bothma, J.P.; Esposito, E.; Ng, S.; Stefanik, L.; Tsui, C.; Johnston, J.; Chen, K.; Gilmour, D.S.; Zeitlinger, J.; et al. Paused Pol II coordinates tissue morphogenesis in the Drosophila embryo. Cell 2013, 153, 976-987. [CrossRef]

179. Buettner, F.; Natarajan, K.N.; Casale, F.P.; Proserpio, V.; Scialdone, A.; Theis, F.J.; Teichmann, S.A.; Marioni, J.C.; Stegle, O. Computational analysis of cell-to-cell heterogeneity in single-cell RNA-sequencing data reveals hidden subpopulations of cells. Nat. Biotechnol. 2015, 33, 155-160. [CrossRef]

180. Battich, N.; Stoeger, T.; Pelkmans, L. Control of transcript variability in single mammalian cells. Cell 2015, 163, 1596-1610. [CrossRef]

181. Ansel, J.; Bottin, H.; Rodriguez-Beltran, C.; Damon, C.; Nagarajan, M.; Fehrmann, S.; François, J.; Yvert, G. Cell-to-cell stochastic variation in gene expression is a complex genetic trait. PLoS Genet. 2008, 4, e1000049. [CrossRef]

182. You, S.-T.; Jhou, Y.-T.; Kao, C.-F.; Leu, J.-Y. Experimental evolution reveals a general role for the methyltransferase Hmt1 in noise buffering. PLoS Biol. 2019, 17, e3000433. [CrossRef]

Publisher's Note: MDPI stays neutral with regard to jurisdictional claims in published maps and institutional affiliations. 